\title{
Parents of children with cancer: integrative review of questionnaires to assess their quality of life
}

\author{
Mônica Aparecida Porto ${ }^{1}$, Marysse Lanes ${ }^{2}$, Maria Teresa dos Santos Guedes ${ }^{3}$, \\ Ana Claudia Frazão Paiva ${ }^{4}$, Raquel Maria de Sena ${ }^{5}$ \\ 1, 2, 3, 4, 5 (Oncologic Nurses, Outpatient Clinic of the Brazilian National Cancer Institute)
}

\begin{abstract}
Objectives: To identify the existence of instruments to assess the quality of life of parents of children with cancer and to gather the most common effects that occur in them.

Methods: Integrative review study of literature on the Quality of Life Parents of children with cancer, to search the database on the website of Virtual Health Library, which houses the MEDLINE and LILACS selecting articles from 2012 to 2016.
\end{abstract}

Results: Sixty-one publications were found after processing the exclusion, only seven of them met the preestablished inclusion criteria. Most of the 7 studies that composed this review 4 were in the English language and 3 in Portuguese and used the following questionnaires: Family Symptom Inventory, Whoqol-Bref and the Zarit Scale, Shirom-Melamed Burnout Questionnaire, Families Scale Scores, Depression Anxiety And Stress Scales, Impact of Event Scale-Revised, Satisfaction with Social Scale, and Burden Assessment Scale, WhoqolBref and SERVQUAL Questionnaire, Caregiver Burden Scale, and QV by the SF-36 and General Comfort Questionnaire (GCQ).

Conclusion: We think that studies should be developed about the physical and emotional status of caregivers of children with cancer, as they interfere in the recovery of these children. And family caregivers also suffer from the overload of care needed for cancer treatment. The results obtained through research can base the construction of plans of care also directed to family caregivers.

Keywords: Caregivers, Child, Nursing, Quality of life, Surveys and Questionnaires, Neoplasms

\section{Introduction}

The word cancer comes from the Latin word "crab", possibly by obstinacy by which it adheres to any part. Academically is called "neoplasm", that is new formation. Studies pointed out that the diagnostics of cancer directly influence the well-being and the quality of life of the patients, especially in the family context, recreation and personal suffering [1].

The possibility of presence of any disease in any family member already brings anxiety, doubts and preoccupations to all members that lives with the same. When the disease is confirmed, and mainly when is a chronic disease, like cancer, the mutual suffering between the patient and the family is potentialized because this disease so feared by the population, is a real stigma, bringing with it psychological factors which tend to enhance the aforementioned suffering $[2,3]$.

Most of the time, the patient is the one who gets the attention from several professional areas during his treatment, meanwhile the parents are seen as those who provide support during the process of caring, letting go unnoticed there emotional and physical needs, that is, they go through painful moments too, of anxiety, doubts and anguish, but also by a break in their daily lives and they need support as well to strengthen their energies to convey to their loved one a quality care [2].

During the impact of the diagnosis of the disease and the treatment, even the suffering, is the main caregiver, the guardian, who has the responsibility to care his loved one, take important decisions, execute the daily activities, to fight against the difficulties to execute the care. Regarding the care provided, the parents fully assume this role, which consequently, can lead to great wear and tear on them. They tend to be emotionally destructive, although they avoid lettings their own feelings show to save the sick, but seek emotional support on the family, in the team and other companions [4].

The biopsychosocial changes that occur in parents of children with cancer will determine different placements that will require different care. Thus, evaluation parameters will have to be specific to contemplate at different stages with different needs of parents [3].

Therefore, it raises the problem that it is necessary in the daily practice of nursing the use of an efficient instrument to evaluate the quality of life of the parents of children with cancer, enabling them to raise their reactions and analyze their influence or interference in the treatment of the child, aiming at a plan of nursing care for parents too. 
Given the relevance of the theme, there was an interest in developing a integrative review of the literature, with the objectives of identifying the existence of instruments to assess the quality of the life of parents of children with cancer and to gather what are the most common effects that occur in them under treatment.

\section{Methodology}

An integrative review of literature was developed through the search of health database in the English, Portuguese and Spanish languages. The database was the Portal of the Virtual Library, which houses MEDLINE and LILACS. The descriptors used were "Family", "Caregivers", "Child", "Minors", "Adolescent", "Medical Oncology", "Pediatrics", "Nursing", "Neoplasm", "Surveys and Questionnaires", "Quality of Life". The inclusion criteria of the article selected in the review were as follows: that they deal with the quality of life of parents or caregivers of children with cancer; Quality of life of caregivers of cancer patients; Questionnaires or scales that assess the overload and the quality of life of caregivers of cancer patients; Publications from 2012 to 2016, texts that were available online in English, Portuguese and Spanish. Exclusion criteria were: restricted access; references of studies that did not deal with the proposed theme; references from studies that appeared repeatedly in the database; language other than those proposed.

In the month of September 2016, the search was initiated by the databases and using the descriptors mentioned above, crossing them. Finally, the filters inserted: period $=2012$ to 2016 and language $=$ English, Portuguese and Spanish. Regarding the duplicity of the studies, found in more than one database used in the research, it was verified the need to exclude the copies, with only one version to be analyzed.

\section{Results}

There were 61 references in the databases searched. After the selection through the titles, there were 34 references left. After processing the deletion, only 7 had met the pre-established criteria. Most of the 7 studies that composed this review 4 were in English and 3 in Brazilian Portuguese. In the last ten years, health professionals who have followed and treated children with cancer have been observing that the diagnosis and treatment of cancer in children seriously shakes the emotional state of the parents and this interferes negatively with the care given to them [2].

In general, the most frequent positive and negative effects (table 1) occurring in the parents of children with cancer, from diagnosis to hospitalization, are presented hereafter. There are more negative than positive effects.

Table 1. Frequent positive and negative effects occurring in the parents

\begin{tabular}{|c|c|}
\hline Positive effects & Negative effects \\
\hline $\begin{array}{ll}\text { - } & \text { Tranquility } \\
\text { - } & \text { Inner Strength } \\
\text { - } & \text { Respect } \\
\text { - } & \text { Hope } \\
\text { - } & \text { Acceptance }\end{array}$ & 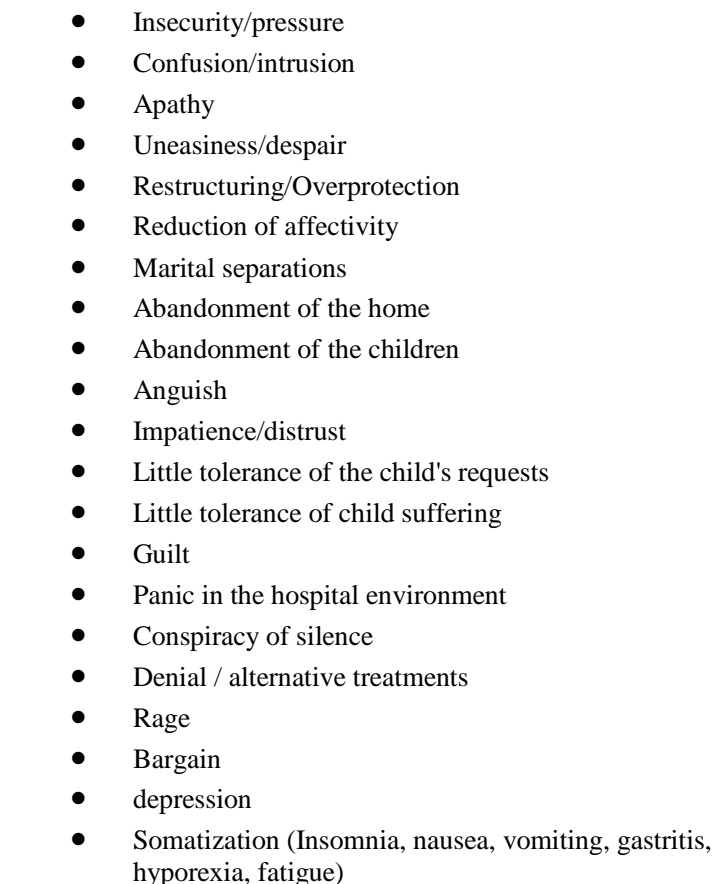 \\
\hline
\end{tabular}


The main causes of these effects are described next (table 2).

Table 2. Main causes of negative effects on parents of children with cancer

- Difficulty of accepting your child's illness

- Difficulty of acceptance of your hospitalized child

- Lack of knowledge about the disease and its prognosis

- Child is always considered very fragile and with high possibilities and longevity

- Personal routines and independence were halted

- Less willingness to care for the child in a different environment

- Having to take care of the child

- Interruption in family routine

The literature review evidenced different instruments for evaluating the quality of life and overload of caregivers of cancer patients, the synthesis of which is shown in table 3 .

Table 3. Synthesis of the references

\begin{tabular}{|c|c|c|}
\hline References & Questionnaires & Synthesis of results \\
\hline $\begin{array}{l}\text { Karlson C.W. et al, 2015, J } \\
\text { Pediatr Hematol Oncol. }\end{array}$ & $\begin{array}{l}\text { Family Symptom } \\
\text { Inventory }\end{array}$ & $\begin{array}{l}\text { The authors created and tested a brief road } \\
\text { map for psychological and other symptoms } \\
\text { such as pain and sleep disorders called } \\
\text { Family Symptom Inventory (FSI). He } \\
\text { concluded that the FSI proved to be valid } \\
\text { and have good internal reliability for } \\
\text { psychosocial screening, which may lead to } \\
\text { improved quality of care in children with } \\
\text { hematologic cancer. }\end{array}$ \\
\hline $\begin{array}{l}\text { Samky F. O. A. et al, 2014, } \\
\text { Psicologia: Ciência e } \\
\text { Profissão. }\end{array}$ & $\begin{array}{l}\text { Whoqol-Bref and Zarit } \\
\text { Scale }\end{array}$ & $\begin{array}{l}\text { Family members were assessed using the } \\
\text { Whoqol-Bref questionnaire and the Zarit } \\
\text { Scale, which showed that caregivers feel } \\
\text { overwhelmed, but the overload is } \\
\text { camouflaged as they do not feel } \\
\text { comfortable disclosing their feelings and } \\
\text { feelings of guilt that are considered } \\
\text { inadmissible. }\end{array}$ \\
\hline $\begin{array}{l}\text { Lindahl N.A et al, 2014, } \\
\text { Pediatr Transplantation }\end{array}$ & $\begin{array}{l}\text { Shirom-Melamed Burnout } \\
\text { Questionnaire }\end{array}$ & $\begin{array}{l}\text { An instrument called the Shirom-Melamed } \\
\text { Burnout Questionnaire was used for } \\
\text { parents. Burnout between fathers and } \\
\text { mothers was associated with severity with } \\
\text { children's health problems. This situation } \\
\text { has decreased after transplantation, but } \\
\text { parents need to be monitored and receive } \\
\text { psychological support for well-being. }\end{array}$ \\
\hline $\begin{array}{l}\text { Shortman R.I et al, 2012, } \\
\text { Child: care, health and } \\
\text { development }\end{array}$ & Families Scale Scores & $\begin{array}{l}\text { One study evaluated parents of children } \\
\text { who had brain tumors through the Families } \\
\text { Scale Scores scale. They concluded that } \\
\text { families of children with this diagnosis } \\
\text { experience a high negative impact which } \\
\text { makes it difficult to cope with stress. For } \\
\text { this reason they need help and support }\end{array}$ \\
\hline $\begin{array}{l}\text { Teixeira R.J et al, 2012, } \\
\text { Psycho- Oncology }\end{array}$ & $\begin{array}{l}\text { Depression Anxiety and Stress } \\
\text { Scales, Impact of Event Scale- } \\
\text { Revised, Satisfaction with } \\
\text { Social Support Scale, and } \\
\text { Burden Assessment Scale. }\end{array}$ & $\begin{array}{l}\text { The study used } 4 \text { instruments to assess } \\
\text { depression, stress and overload. It has been } \\
\text { found that social support can be a mediator } \\
\text { in the relationship between psychological } \\
\text { imbalance and the caregiver's overload. }\end{array}$ \\
\hline $\begin{array}{l}\text { Saijjaid H et al,2013, Global } \\
\text { Journal of Health Science }\end{array}$ & $\begin{array}{l}\text { Whoqol-Bref and } \\
\text { SERVQUAL } \\
\text { Questionnaire }\end{array}$ & $\begin{array}{l}\text { The authors assessed the quality of life of } \\
\text { family caregivers through WHOqol-Bref } \\
\text { and the SERVQUAL Questionnaire. They } \\
\text { found that providing high-quality services } \\
\text { to patients is one way to promote quality } \\
\text { of life and caregiver satisfaction. }\end{array}$ \\
\hline $\begin{array}{l}\text { Rubira E.A et al , 2012, Acta } \\
\text { Paul Enferm }\end{array}$ & $\begin{array}{l}\text { Caregiver Burden Scale } \\
\text { and SF-36 }\end{array}$ & $\begin{array}{l}\text { Used on the Caregiver Burden Scale and } \\
\text { SF } 36 \text { scale to assess overload and quality } \\
\text { of life. They found several domains in } \\
\text { quality of life, which puts in danger the } \\
\text { quality of care provided to children and } \\
\text { cause mismatches in the health of the } \\
\text { caregiver. }\end{array}$ \\
\hline
\end{tabular}


After reviewing the literature, it was noticed that only two instruments for assessing the quality of life and burden of family caregivers are translated and validated in the Brazilian Portuguese, the Whoqol-Bref and the SF-36.

\section{Conclusion}

We think that studies should be developed about the physical and emotional status of caregivers of children with cancer, as they interfere in the recovery of these children. And family caregivers also suffer from the overload of care needed for cancer treatment. The results obtained through research can base the construction of plans of care also directed to family caregivers.

\section{References}

[1]. N Choenyi,M Kumari, S Choedon, M Kumari, S Kumari, I Kumari, S Kumari S Charan and K Bala, Knowledge Regarding III Effects of Chemotherapy and Its Home Management among patients Receiving Chemotherapy, IOSR Journal of Nursing and Health Science, 5(3), 2016, 25-29.

[2]. EARE Santo, MAM Gaiva, MM Espinosa, DA Barbosa and AGS Belasco,Taking Care of Children With Cancer: Evaluation of the Caregivers' Burden and Quality of Life,Rev.Latino-Am.Enfermagem, 19(3), 2011, 515-522.

[3]. ARM Beck and MHBM Lopes, Caregiver role strain in caregivers of children with cancer, Revista Brasileira de Enfermagem, 60(5), 2007, 513-518.

[4]. MLC Duarte, LN Zanini,MNB Nedel, The daily routine of parents of children hospitalized with cancer: nursing challenges. Revista Gaúcha de Enfermagem, 33(3), 2012, 111- 118.

[5]. VA Angerami, E a psicologia entraram no hospital (São Paulo, Pioneira Thomson Learning, 2003).

[6]. FNP Doca and ALC Junior, Psychological preparation for pediatric hospital admission: a short review, Paidéia, 17(37), 2007, 167179.

[7]. K Milanesi, N Collet and Brg Oliveira, Psychological suffering of the families of hospitalized children, Revista Brasileira de Enfermagem, 59(6), 2006, 769-774.

[8]. JP Pinto, CA Ribeiro and CV Silva. Trying to maintain the equilibrium to serve their demands and take care of hospitalized children: the family experience, Revista Latino- Americana de Enfermagem, (13)6, 2005, 974-981.

[9]. S Sharma and RK Mehta, Level of Depression among Family Care Givers of Cancer Patients, IOSR Journal of Nursing and Health Science (IOSR-JNHS), 4(3), 2015, 39-47.

[10]. GSN Morais and SFG Costa, Existential experience of mothers of hospitalized children in Intensive Pediatric Care Unit*, Revista da Escola de Enfermagem da USP, 43(3), 2009, 639-646.

[11]. CW Karlson, S Haynes, MA Faith, TD Elkin, ML Smith and G. Megason, Development of the family symptom inventory: a psychosocial screener for children with hematology/ oncology conditions, J Pediatr Hematol Oncol, 37(2), 2015, $140-146$.

[12]. FOA Samky, RF Alves, MO Melo and MJ Rodrigues, Qualidade de vida e sobrecarga de cuidadores de crianças com câncer, Psicologia: ciência e profissão, (34)4, 2014, 1014-1031.

[13]. AL Norberg, K Mellgren, J Winiarski and U Forinder, Relationship between problems related to child late effects and parent burnout after pediatric hematopoietic stem cell transplantation, Pediatric Transplantation, 18, 2014, 302-309.

[14]. RI Shortman, A Beringer, A Penn, H Malson, SP Lowis and PM Sharples, The experience of mothers caring for a child with a brain tumour, Child: care, health and development, 39(5), 2012, 743-749.

[15]. RJ Teixeira and MG Pereira,Psychological morbidity, burden, and the mediating effect of social support in adult children caregivers of oncological patients undergoing chemotherapy, Psycho-Oncology, 22, 2013, 1587-1593.

[16]. H Sajjadi, M Vameghi, M Ghazinour and MK Ardakani, Caregivers' Quality of Life and Quality of Services for Children with Cancer: A Review from Iran, Global Journal of Health Science, 5(3), 2013, 173-182.

[17]. EA Rubira, SR Marcon, AGS Belasco, MAM Gaiva and MM Espinosa, Sobrecarga e qualidade de vida de cuidadores de criança e adolescentes com câncer em tratamento quimioterápico, Acta Paul Enferm, 25(4), 2012, 567-573. 